\title{
PATRIARCHY AS A SOCIAL TRIBAL VALUE: FEMINIST ANALYSIS OF JAMIL AHMAD'S THE WANDERING FALCON
}

\author{
Gulnaz Sattar ${ }^{1 *}$, SaimaYasin ${ }^{2}$, SayyedaFarihatulaen Rizvi ${ }^{3}$, Afshan Khalid ${ }^{4}$ \\ ${ }^{1,4}$ Lecturer, Department of English, National University of Modern Languages, Multan Campus). \\ ${ }^{2}$ Lecturer, Department of English, University of Jhang. \\ ${ }^{3}$ Lecturer, Department of English, National University of Modern Languages, Islamabad Campus.
}

\begin{abstract}
The present study is aimed to investigate the status of women in the novel The Wandering Falcon by Jamil Ahmed originally published in 2011. The Wandering Falcon is a collection of nine short stories. All the stories are interlinked with one another. The novel shows life in the tribal areas situated at the borders of Pakistan, Iran and Afghanistan. In the present study, the researcher has examined the impacts of tribal traditions and rules on the lives of the people of these region. The research deals with the cruel and brutal laws of Federally Administrative Tribal Areas (FATA) and the miserable life style of these tribal people, especially the women of the region, as depicted in the novel. The tribal people have to face the indifference of nature as well as the supremacy of society. The rules and regulations of society have a deep impact on the social, mental and psychological development of its members. The present study deals with the social status of women in these tribal areas. It describes the attitude of tribal customs and traditions toward women and reflects the impact of these brutal laws on the lives of women as well as the poor and suppressed class of the society. This article aims to highlight the tribal customs which, commodify the women of FATA. Qualitative research paradigm has been selected for the novel as it tends to be exploratory and interpretative and feminist perspective have been applied on the sample.
\end{abstract}

Keywords

Patriarchy, feminism, tribal customs.

Article Received: 20 September 2020, Revised: 30 November 2020, Accepted: 18 December 2020

\section{Introduction}

From the very inception of human history, women play a vital role in the creation of an ideal society. Man, and woman are both equal and no gender holds any supremacy over another by nature. It is necessary to give them the basic human rights or freedom so that they can work easily according to their desires and for the betterment of life for themselves and for the other members of the family or society. It is one of the prime facts that from the commencement of life on the earth, women have to suffer more than men in order to get their rights or to perform their role in the betterment of society. They are always considered an inferior being in society. It is the tradition of the world that man always sets rules for society as well as for their other fellow beings. Women have to follow the terms set by men. From the very start of human history man is considered superior to women. Adam was created first, and Eve was created out of his rib. He also gave name to Eve, his wife (Genesis, 3:21). Therefore, women are all the time considered inferior to men. The feminists think that women have an equal status as compared with men because they equally take part with men in all the fields of life; they do work in their homes as well as they do other jobs outside the home to support their family (Abbas, 2017, p. 1).

Jamil Ahmed replicates the harsh realities of women in The Wandering Falcon. The Wandering Falcon shows the nasty life of women in tribal areas. Being a woman becomes the most terrible fact. The role of women in this society is nothing but to obey the orders of others. They have no right to speak in front of the male members of the family. They cannot express their choice or life according to their will. They have to yield before the regulations of patriarchal society. Gender discrimination stays a significant hindrance to human development. Women, girls and transgenders are facing the problems of gender discrimination; they are significant source of inequity in the society. Women are discriminated in all spheres of life that includes health, education, politics, maternal health and economy. Pakistan has been ranked the second worst country in the world for gender inequality. The educational status of Pakistani women and transgender is among the lowest in the world. In a country like Pakistan, the moment a girl is born, most of her decisions have already been made. However, when a baby boy is born, his family would give him a chance to do whatever he pleases. A woman in the classical Pashtun culture has to depend on the male family member in almost every sphere of life.

One of the prominent features of the novel The Wandering Falcon by Jamil Ahmad is the patriarchyin the culture of the Baloch tribes. It has been portrayed that females are restricted in their roles in not just their homes, but overall in the society. Their primary focus is to tend the men of their house. Different chores like cleaning and cooking are their major duties of women in the Pashtun society. They are not allowed to talk in the matters outside the household. No woman has the courage to question the norms of the society. There is no judicial system that may defend for the rights of 
women or at least speak for them as these areas are not ruled by any specific government. The researcher has analyzed the incidents of patriarchy as portrayed in the novel.

\section{Statement of the Problem}

Despite the numerous gender discrimination laws and court rulings, women are subjected to un-equal treatment in all spheres of life all over the country, especially, Baluchistan. Patriarchy is one of the major hindrances in the development of the Pashtun society. The roles of women in a Pashtun culture are restricted to household activities. They are not allowed to speak about matters which do not involve cooking, sewing or cleaning etc. Women are rarely allowed to read or write. They are not allowed to go outside without permission. Because of these hindrances, the vast majority of the population (Pashtun women) of the country is not working for the development of Pakistan. The current research has analyzed how in The Wandering Falcon, Jamil Ahmad portrayed the plague because of which women are portrayed to be deprived of the basic rights.

\section{Significance of the Study}

This study highlights the prevalence of patriarchal culture even in modern societies. It raises an important issue which hinders the progress of the whole country. The current study not just facilitates the social arena by highlighting the patriarchal setup but also intends to aid the students of literature in getting a profound understanding of the selected topic especially by highlighting the status and plight of women in the tribal areas of Pakistan.

\section{Research Objectives}

The research objectives of the current study are:

- To portray the incidents depicting 'Patriarchy' in The Wandering Falcon by Jamil Ahmad

-To explore the effect of patriarchy on the characters of the novel

-To analyze the significance of honor in the Baloch tribes

\section{Research Questions}

1.How is patriarchy employed through the instances and actions of people around the protagonist?

2.How does Jamil Ahmad portray the significance of honor in the Pashtun society?

3. How is patriarchy a hindrance in the success of Pakistan?
Delimitations of the Study

The study focuses on the feminist analysis of the novel The Wandering Falcon by Jamil Ahmad.

\section{Literature Review}

Patriarchy is a culturally loaded term and has been defined differently by different feminists. Mitchell defines the term "to refer to kinship systems in which men exchange women" (Mitchell 1971:24). Another feminist critic explains it as "patriarchy as a system of social structures and practices in which men dominate, oppress and exploit women" (Walby 1990:20). For Walby patriarchy is an organized system whose central aim to is create male hegemony by rejecting the biological truth related to gender and sex. This system advocates the biological difference between a man and women hence, performs different roles ascribed by society.

After reading many feminist critics definition of the term, one inference can be generated about patriarchy is that is a very systematic process of putting men at the dominant position of a household and a society. Patriarchal systems propose that "men hold power in all the important institutions of society", they further contend that women are powerless because of their sex and are inferior to men (Lerner 1989:239). Engels has given a very comprehensive discussion on the development of the patriarchal system in his seminal work The Origins of the Family, Private Property and the State (Engels 1940). He argues that subjugation of women started when women began to own property which was highly unacceptable for men. Men wanted to hold a dominant position and overthrow the mother rights, especially their claim on property. Women had to be domesticated in order to be subjugated and controlled by them which they eventually achieved. And this is how men got to the dominant position and led to the development of patriarchal systems. For a long time patriarchal systems remained unchallenged until the development of feminism. Feminism and feminist critics took the issue of patriarchy and inferior status of women into their writing.

Digambar S. Kulkaaniclaims that writers denote the story of the entire society through their writings (literature). Jamil Ahmad who is one of the famous Pakistani writers, keenly observed the tribal communities of Pakistan, the important region where Pakistan, Afghanistan and Iran meet, and he described the life styles, cultures, and traditions in his great piece of work. Ahmed portrays the actual picture of tribal life by various situations and events related to tribal people. He focuses on all the aspects of society such as political, cultural, and gender issues. The Sins of Mother, the very first story of the novel shows the bitterness of tribal rules. It depicts the life of Gul Bibi and her lover and shows the painful event of their death. According to the tradition of tribe, the adulterous couple has to face stoning until their last breath.The Sins of Mother, The Death of Camel, Pond of Opium and Sale Completed all these stories show 
different female characters in dissimilar situations but there is one common thing among them and that is they all become the victim of patriarchal society and the harsh rules of their tribes (2018).

Poonam Valera and Dr Vipul V. Makodia claim that The Wandering Falcon takes its readers to the journey of Pakistani tribal areas and charmingly interprets human passions, feelings, and problems of life. While reading the book, the reader considers himself in another world. Ahmed narrates the life of a nomadic tribe (powandas). He describes how tribal people have to keep their animals (dogs, flock of sheep, etc.) with them all the time because their animals are very important for their survival. They travel from Pakistan to Afghanistan and from Afghanistan to Pakistan years by years. These people are like wandering birds; they have no specific statehood, no identification and no citizenship. Ahmed describes the lives of several Balochi tribes. The period of 1950s and 1960s is portrayed as a crucial time for tribal people due to the strict border policies. It seems that all the characters of the story are fighting the battle of their survival, especially the female characters like Shah Zarina and Sherakai. They run-away from domestic ferocity and their quest for peace takes them to another world (2017).

The Wandering Falcon by Ahmed is a compilation of short stories and the main character Tor Baz (Black Falcon) connects these stories with each other. Borders play a significant role in this work and it can be sited under the border philosophy. It paints the effects of borders on the lives of human beings, their psychology, their societies and behaviors. This literary writing deals with the same situation and it shows the power of authority and the struggle of passers. The setting of the book is essential, as borders are not considered hurdles untying nation states today. However, it develops the regions of liminality of cultures where conveying, communication, and movements are drawn. The exploitation of border people by the hands of officials is also reflected in this book (Wasif, 2010).

Syed ArifHussaini opines that The Wandering Falcon is a story of devotion, obligation, revenge, friendship and tribal association. Ahmed represents the similar economy of words as used by Hemingway in his marvelous creation The Old Man and the Sea'. Ahmed may not be as great a storyteller as Manto or Hemingway but with his debut novel, he has indeed carved a niche for himself among the outstanding writers (2011).

Zanyar Kareem Abdul, a student of MA English literature (University of Sulaimany), in his article The Silence of Women in Toni Morrison's Paradise published in International Journal of Scientific Research says that Morrison is an outstanding literary figure in Modern American literature. She is well known for the depiction of black society in America. Toni Morrison is a Nobel Prize winner and a distinguished American feminist writer. She was occupied with Virginia Woolf and Leo Tolstoy in her literary lifetime. The sequence of Beloved (1987) and Jaz (1992) is completed by Paradise (1997). The focus of
Morrison is her treatment and portrayal of black woman. Many black writers deal with the status of black women.

The black woman writers used the tool of language to motivate and guide the blacks, especially the black women to fight for their rights. Their writings show a very vivid picture of the circumstances and conditions which women faced by the hands of their lords and male family members. These writers instigated women to stand against the vices of slavery and oppression. For example, in Beloved by Morrison, Sethe kills her children to save them from the vicious and brutal curse of slavery. The Color Purple by Alice Walker shows the struggle of a woman against the socalled rule of family. The protagonist of the novel The Color Purple, Celie, fights against her family for ruthless and cruel traditions of the patriarchal society. She strives hard to attain an honorable and respectful status in a male dominated society and finally she is able to have some worth in the society to be regarded.

Maya Angelou's autobiographies are the best examples of the struggle of the women for their status and position in the society. Audre Lorde, through her writings, motivated the Black women to take an active part in the Civil Rights Movement to fight for freedom. In fact, the African American women writers played a vital role for the uprising of women of their community to get freedom from the men of their society at one side, and from the Whites on the other (Abbas, 2017, p. 4)

Morrison, the African American black Nobel Prize winner novelist, has tried to highlight the issues of women in her novels. She raised the voice of women's double marginalization through her works. Paradise shows the treatment of women and gender discrimination between black and white women. The treatment of women is the major theme of The Bluest Eyes (1970) and the exploitation of these women. Morrison tells the standards of beauty according to society, blonde hair as well as blue eyes. She is the main character of the novel and her parents always fight in words and materially. Even she became the victim of her stepfather's brutality who raped her many times. After destroying her life, he leaves her with a kid. Pecola always remains in an inferiority complex due to her ugliness and lack of "Blue Eyes" (which is a symbol of beauty at that time). Morrison used the treatment of black women as the theme of her most novels and in her novels, she beautifully portrays the desire of black women for white skin. Pecola never loves herself as she always observes the things in her life from the perspectives of the others. She becomes the victim of Anglo-Saxon standards of beauty as well as the prey of the chauvinist and prejudiced domination. All the female characters of the Paradise have to face oppression of men thus, remain silent in order to survive in society. (Abdul, 2014)

Morrison's another novel A Mercy is continuation of her novel Beloved. Both the masterpieces of her art emphasize on the different situations of blacks distressed physically, emotionally and spiritually by whites. Completely, the 
novels encircle the circumstances how blacks have frequently been drowned in the ocean of racial discrimination and have been brutally and inhumanly victimized throughout their lives; physically, emotionally and sexually, by their white dominant masters. The writer brings the problems with particular reference to freedom and equality of blacks realistically through the characters of her novels to presents the psychological and emotional factors of blacks (Rahim, 2018).

The life of Sethe, the protagonist of the novel Beloved, is the representative of the cruel life undergone and suffered by slave women brought from Africa, which has resulted in the sense of complexity and disaffection found in the black women. Not only Sethe but other slaves in this novel also become the victims of suppression and all slave women are separated from their small children. They are treated as animals and exploited not only as workers but also as breeders of new property i.e. their children. The children, newly born out of their slaves, were also bound to obey their white masters (Rahim, 2018).

E. Dhivya (2016) says that African American authors create the form of African American literature. Few distinguished writers such as Morrison, Angelo and Mosely deal with the issues of equivalence, oppression, and discrimination. Life becomes more difficult for a woman and particularly for colored women. The black women are doubly marginalized; they have to face the viciousness of white men as well as white women moreover at the same time they have to face the brutality of black men as well (Aydemir, 2012).

Alice Walker is one of the renowned African American writers. She describes the gender issues in her writings by focusing on many versatile aspects of human life such as motherhood, the relation between mother and daughter, companionship between men or women. She has written poems, short stories, essays and novels. Her writings highlight the African American culture as well as the problems of her community in life. Her award-winning novel The Color Purplereceived the Pulitzer Prize as well as National Book Award for fiction in 1983. She wrote about the experiences of her family, friends and relatives (Editors, 2014). The novel The Color Purple starts with rape scene, the fourteen years old leading character of the novel is raped by her step farther. Walker depicts the experiences of relatives and family in her novels the rape scene of the novel is based on Walker's great-great- grandmother. Her master raped her when she was only 11 years old. (Whinchell, 1992) The Color Purple' is an epistolary novel and portrays the pitiable life of a girl, Celie, who wrote letters to God to share her, in order to share her sufferings. Walker shows the invisible voice of women in her novel as well she depicts the fight of women with the pitiless laws of society (Walker, 1985).

\section{Research Methodology}

This research follows the qualitative method and is descriptive in its design. The researchers have gone through the text of The Wandering Falcon by Jamil Ahmad to analyze the instances highlighting the patriarchal system and plight of women in the selected fiction along with which the instances depicting the importance of honor in the nomadic tribes of Balochistan have also been analyzed.

\section{Theoretical Framework}

History of feminism tells us that there have been three waves of feminism and their prime objectives were to advocate for women and their social status, highlighting their struggle against an oppressive patriarchal system. Feminism has led to the development of various schools of thoughts each highlighting a different aspect of female struggle. One of the prime struggles of feminism has been against the oppressive system of patriarchy. Patriarchy comes from the word patriarch where a single male dominates the entire household similarly, a patriarchal society is led by men where others, especially women, are considered inferior (Bhasin, 2006). Patriarchy in The Wandering Falcon constitutes the ways of living, the ethical codes and the cultural beliefs and disbeliefs of the tribes particularly Siahpads, Brahui, Kharot, Pawindahs, Waziris, Mahsuds, Afridis and other Baluchi tribes. These tribal communities treat women as an inferior object of pleasure with no self-autonomy, as depicted in the novel under analysis. Mary Wollstonecraft considers lack of education as the primary reason for inferior status of women. A Vindication of the Rights of Woman (1792) by Wollstonecraft provides the theoretical base for this research paper. She contended that throughout history women's role has been less of a man, existing only to provide pleasure to the men. For tribal communities of FATA as in The wandering Falcon mistreating women, owning women or selling women is part of the honor of any tribal system. This man dominated value system of tribes is similar to the patriarchal system which is highly criticized by feminists for their faulty concepts of social and political involvement of women.

Wollstonecraft has provided the concept of 'National Education', which consist of both sexes, and provide opportunities to both men and women in unfolding their faculties. Her theory postulates that women are in no way unequal to men, they are considered inferior only because of their lack of education. She further argued for political and social reforms in the educational and political setup of any country as means to strengthen women. She proposed the idea that men and women should be given equal opportunities in work, politics and education (Craciun, 2013) 
Analysis

In TheWandering Falcon, Ahmed gives a vivid picture of the FATA and keenly observes the social status of women in this man centred society. FATA is a remote and underdeveloped area of Pakistan, the people of these areas have to fight with several social problems such as unemployment, ignorance of law, low social, economic situation, etc. in order to win the battle of existence. The condition of women is worse as they have no basic privileges and are treated like an object of trading. Occasionally, men use women to save their lives from their enemies, and sometimes sell them in order to get the money. They use them to satisfy their drives and at times kill them in the name of honour. To gratify their ego, these tribal men torture women psychologically and physically.

Ahmed shows this situation by many incidents in his work and he describes the story of an eloped couple; a young girl and boy leave their homes but unfortunately, they become the victim of a group of ruffians. These rogues dishonoured the girl, their instincts do not satisfy from this misdeed, and they sport with the man too. After doing all this, they went away by leaving the couple. The young man indicts the girl for this tragedy and he blames her that she does not do anything in order to save her honour and modesty by the other men. The girl replies to the boy that my love is true that these rascals violate my chastity, and it is not a major concern for the reason that a woman's body has been designed for this and it has natural temptation for men. "Now look at yourself, you are a man. You were not made to be used the way these rascals used you. Yet you did not resist them. You allowed yourself to be violated just as I did"(p. 100). Hamesh Gul visits the home of Amir Khan, his father in-law, for the first time after his marriage, as his mother in law cannot recognize him because he and his wife, the daughter of this family, never visit their home again. Even the mother of the girl forgets which of her daughters is married to that man. "Which daughter of mine have you married?" the disembodied voice called back skeptically. "The one after the eldest" (p. 115).

Ahmed states the underprivileged position of a wed woman in tribal society that she cannot see her parents after her marriage without the approval of her husband. "Hamesh Gul had never visited his in-laws, nor had the old woman seen her daughter after the marriage. That was now more than twenty years ago" (p. 115). This bitter reality reflects the status of women that are living a very submissive state of life. The role of women in this society is nothing but to accept the orders of their men and to obey them. Shah Zarina, the eldest daughter of Mullah Fateh Mohammad, marries in the family of ice cutters. Her husband has a trained bear and by demonstrating bear performance, he earns money. They consider this match a wonder by God, as they are not expecting a man of self-governing earnings for their daughter. After the settlement of the bride price, the marriage is planned. Finally, Shah Zarina moves from her father's home to her husband. While passing through different areas, sometimes, after the settlement of the price with her husband, the bear starts performing to amuse people. The journey is frightening for Shah Zarina, as at some places, they have to experience the attack from the groups of dogs while the bear is making people laugh by its performance. "As she stumbled about among yelping dogs and jostling strangers, there were a few stray remarks directed at her, which her husband chose to ignore" (p. 162). At one place, they see some young boys, who are tossing the dirt and shells at an old man and were making fun of him, when they saw the bear and the owner couple of the bear, they start teasing these people by throwing the mud and eggshells to them, but her husband remains silent at this illtreatment. He does not utter a single word in order to save her wife from this attack. "They began throwing stones, and one of them hit the bear on his snout and drew blood. The bear screamed with pain, and at that, her husband took his staff and hit at the boys and managed to disperse them" ( $p$. 163). The reaction of Shah Zarina's husband at the pain of the bear indicates the approach of typical man centred society where woman is one of the worthless creatures, even though she has less importance than the animals and she is treated like animals.

Shah Zarina and her husband take a room on rent and this room is set for the bear in the night and Shah Zarina can without restrictions use the room in morning, in the absence of the bear. She sets her dowry according to her desire. "In the afternoons, they had to be put together, tied up, and removed so as to have the room ready before the bear returned" (p. 163). Shah Zarina's life is one of the truest representations of women social status in the tribal areas. They are living the worst life and even more awful than animals. Shah Zarina cannot understand the significance of the bear as she asks her husband about this thing. "He looked at her coldly and said, "I can get another wife but not another bear." She was bewildered" (p. 162)

Ahmed indicates the psychology of the patriarchal society where a woman is treated as an object of exchange and she has no right to speak in front of the man. Shah Zarina's husband astonished her by saying that his bear is more valuable for him than his wife is. With the passage of time, the attention of his husband towards the bear makes Zarina jealous. She does not like such love for an animal. It is one of the disgusting things for her that an animal has more status and she has no position and is treated desperately. This detestation makes her revolt against this cruelty and she starts to take revenge from the bear. "One day she would pour water in the corner where the bear was tied and imagined it passing an uncomfortable night. Another day, she scattered some thorns on the floor" (p. 164). Because of the feelings of subservience and eager to avenge her opposition, she starts doing some tricks in order to tease the animal. Sometimes, she pours some water at the bear's place and sometimes, mixes some chilies in its food. "Finally, she hammered small nails at the end of the staff her husband used to beat the bear with every morning to ensure good behaviour during the day" (p. 164). In the morning, few cuts appear on the skin of the bear and the bear starts crying with pain. The terrible situation of the bear makes the owner 
worry but when he understands the whole situation, he reacts very harshly over her: "At that, her husband took the same staff and gave his wife exactly the same number of blows as he had given the bear. From then on, Shah Zarina's life underwent another change for the worse" (p. 165). After these incidents, her husband makes the condition worse for her and her comfort is associated with bears. After the bear takes its food, Zarina gets her food and if the bear is hungry, she remains hungry. If the bear sleeps comfortably at night, she can join her husband. The most heart touching thing is if the bear faces beating early in the morning in the same way as she has to tolerate this practice. "After a few months of this, Shah Zarina broke down and ran away from her husband" (p. 165).

It turns into a miserable situation for the parents that the eldest daughter runs away from her husband's home and this action can destroy the future of other daughters as well. The failed marital status of the elder sister is a hindrance in the marriages of the younger sisters. The parents are worried about another problem; they were worried about the bride price, which they spent on marriage arrangements.

"Her husband is bound to come by any day. He will demand that she be handed over to him. That is his right. If we refuse, he will ask for the return of the bride price," added her father. "But we have already spent the money!" her stepmother whined. "She has created a terrible problem for us all"(p. 166).

According to the laws of tribal society, a married woman cannot leave her husband's home without his permission and if she runs away, the parents of the girl have to give back the bride price to the man or to hand over their daughter again to her husband. It is impossible for a poor family to pay the money back. In tribal society, it is a compulsion for the woman to wear burkas and to remain in the veil. They are not permitted to move freely without covering themselves from head to toe. "Who were wearing dirty white cotton burkas, the heavy shroud like garments that served to hide a woman's body and veil her face?" (p. 168).

Ahmed keenly observes the miserable circumstance of women in tribal society. They are deprived of basic human rights and have no liberty in life. The definition of life to them is to remain in a submissive, timid position and to obey the rights of their masters. Men treat them as slaves and animals or some object of trading and the ownership of this property is transferred from one to the other and the tribal men do not hesitate to exchange this commodity. Women have to live subhuman lives even if they are sold in the markets as slaves. Those poor and helpless women that leave their homes due to terrible circumstances become the victim of some vicious men and they use them for their benefit and sell them in slave markets. "They smiled secretly at each other. Thursday was the sale of women" (p. 172). Afzal Khan, a woman trader, reaches a notorious market of women selling along with two women, Shah Zarina and Serakhai. The three of the people meet on the journey and they stay at a hotel in order to wait for the selling day which is Thursday. The attendant of the hotel, a young boy, feels pain when he sees two new faces for sale. He used to see new faces every Thursday including the infants, young women and old ones. Every woman comes with a dejected story, the hardships of life and the bitter circumstances force them to take some rebellious steps as they leave the homes of their husbands and their fathers in order to save their lives. Sometimes, a woman comes repeatedly to this place as her owners sell her frequently and some faces come and banish at once. "His memory was only a sea of women's faces, and his small body shook with tension every time he saw yet another face destined to be sold" (p. 173). Yet it was strange that the women had always shown loathing and hatred toward him. He could feel it now, in the two women standing before him" (p. 173). The boy has seen thousands of women that come and go. Despite the fact he is part of the same patriarchal society, yet he feels pain for them. He knows the fact that all these women have come to this stage due to the injustice and cruelty of manmade society, where woman is considered as a worthless thing.

According to Jamil Ahmed, the women of tribal areas have no right to speak in the matters associated with their lives or family. They are considered as the property of their man, as the customs of Sawara and Vulvar are shown as the true representative of this thought process in the novel The Wandering Falcon. By practicing the traditions of Sawara and Vulvar, tribal men consider themselves brave. Due to the low social status women have no significant role in the politics of FATA. Even they are deprived of their right to cast the vote or to express their choice by choosing a leader as being shown through the female characters of the novel under analysis. "In 1996, it was the first when president of Pakistan Farooq Khan Leghari introduced the electoral reforms in FATA and gave the right of universal suffrage to the inhabitants of the region" ( $p .187$ ). The condition of women in the field of education is not different from the other fields of life. According to a survey conducted in 2020 , the literacy rate of women in fata is merely $7.8 \%$.

The ritual of "Bride price" or "Vulvar" states the position of women in Pakistani tribal areas. It is the evidence of the fact that tribal men treat women as commodities and the ownership of this product is shifted from one owner to the other. This tradition has suppressed women socially, psychology and physically. Bride price shows the importance of half of the population in this tribal world. This tradition reflects the reality that woman is not considered a human being but an object to import. The family of bridegroom treats the girl as one of the inferior beings, slightly a commodity they have purchased. This type of relation has the same social status as the relation between the master and servant. The men of girl's family; her father, brothers and uncle take this money. The practice of bride price is lasting from centuries and according to the followers of this tradition, they take money for the benefit of the girl. "General, No man respects his wife or her family unless he 
pays a price for her. But you should be able to get your due without seeking the help of other people's laws" (p. 42).

\section{Conclusion}

Jamil Ahmad has portrayed very beautifully and artistically the social realities of the tribal region, especially the rules, customs and traditions of the area. The traditions and customs of the society are very cruel and brutal, especially for the poor or supressed class of the society. The women are marginalised and suppressed due to the customs and traditions of the society. They are denied from the very basic needs of life, such as education, inheritance in ancestral property, right to cast the vote, choice in marriage and other similar issues. The women are treated like a commodity and they are sold like other things, in the market. They are offered to other members or tribes to settles the disputes among the tribes and resolve the issues. Men as well as the cruel traditions and rules subjugate women in this patriarchal society. The Wandering Falcon reveals the poor social and economic condition of women in Pakhtun tribal areas. All the female characters of the book are representation of male dominance and their cruel behaviour with females. Gul Bibi becomes the victim of brutal tribal laws and she is killed being the victim of Honour killing. Gul Jana meets death due to the arrogance of government laws or authorities as well as the backwardness of this area. Through the female characters of the novel, Ahmed expresses the miserable state of women in the tribal areas. Women are deprived of their basic rights. They are used to please the feelings of men as well as to take the revenge from other tribes. Women are slaughtered in the name of honour. Even they are being sold in markets as slaves and commodities and men buy them for housekeeping and for their business as well.

\section{Works Cited}

* Ahmed, S. Akbar. The Thistle and the Drone. Washington, Brookings Press, 2013.

* Resistance and Control in Pakistan. Routledge, 2004.

* Trials by Ordeal among the Bugtis: Rituals as a Diacritical Factor in Baloch Ethniciy, in Marginality and Modernity: Ethnicity and Change in Post-Colonial Balochistan. Oxford University Press, 1996.

* Abbas, M. R. (2017). Interrogating Gynocentric Perspectives in the Color Purple by Alice Walker. Lahore: National College of business administration and economics.

* Abdul, Z. K. (2014). The Silence of Women in Toni Morrison paradise. International journal of scientific \&emgering research, 1266-1270.

* Ahmad, J. (2014). The wandering falcon.Navi Mumbai: Repro India Ltd.
* Aydemir, Y. (2012). The suffers of black women in Alice Walker's novels 'the color purple' and 'meridian 'and Toni Morrison's novels 'beloved' and 'the bluest eye' . The journal of international social research, 437-444.

* Bhasin, K. 2006. What is Patriarchy? Women unlimited: New Delhi.

* E. Dhivya, (2016) Women as Victims: An Analysis of Alice Walker's The Color Purple

* Editors, B. (2014, April 2). Alice Walker biography. Retrieved July 30, 2018, from The Biography: https://www.biography.com/people/alice-walker9521939

* Engels, F. 1940. The Origin of the Family, Private Property and the State. London : Lawrence and Wishart.

*Hussaini, S. A. (2011, October 21). The wandering falcon-riveting tale about Pakistan's edge. Retrieved August 1, 2018, from Pakistanlink: http://pakistanlink.org/hussaini

* Imran, M. and Gull, A. Victims of honor killing in BapsiSidhwa's the Pakistani bride and Jamil Ahmad's the wandering falcon. European Journal of English Language and Literature Studies. March 2017: 22-27.

* Lerner, G. 1989. The Creation of Patriarchy. Oxford University Press: New York.

* Kulkarni, D. S. (2018). Social realism: Representation of Tribal Culture and Treatment of Women in Jamil Ahmad's the Wandering Falcon. An international journal in English, 1-5.

* Mitchell, J. 1971. Women's Estate. Harmondsworth: Penguin

* Poonam Valer and Dr.Vipul V. Makodia. (2017). Storytelling techniques reflected in Jamil Ahmed's the wandering falcon. Pune research scholar: An international multidisciplinary journal, 1-5.

* Rahim, S. (2018). Investigating racial discrimination in 'mercy' by Toni Morrison. Lahore: National College of business administration and economics.

* Valera, P. and Makodia, V. Storytelling techniques reflected in Jamil Ahmad's 'the wandering falcon' Pune Research Scholar: An international multidisciplinary journal. Jan. 2017.

*Walby, S. 1990. Theorizing Patriarchy. Blackwell publishers Ltd.: Oxford, UK and Cambridge USA.

*Walker, A. (1985). The Color Purple. New York: Pocket Books.

*Walker, A. (2004). The Color Purple. London: Orion Books Limited. 
* Wasif, R. (2010). Utopia Borders: Liminal Zones of Transition and Cultural Creation in Jamil Ahmad's the Wandering Falcon. Forman Christian College University, 1-6.

*Whinchell, D. H. (1992). The Color Purple. New York :Twayne 